\title{
A Re-Examination of the Asymmetry between Interest Rates and Stock Returns
}

\author{
Kenneth Kalu ${ }^{1}$ \\ ${ }^{1}$ The University of Texas at Austin, Austin, USA \\ Correspondence: Kenneth Kalu, The University of Texas at Austin, Austin, TX 78712, USA. E-mail: \\ kenneth.kalu@austin.utexas.edu
}

Received: March 26, 2017

Accepted: April 13, 2017

Online Published: May 5, 2017

doi:10.5539/ijef.v9n6p23

URL: https://doi.org/10.5539/ijef.v9n6p23

\begin{abstract}
The purpose of this paper is to reconcile previous findings of prolonged asymmetrical relationships between interest rates and stock returns, where a reduction in interest rates in one month was shown to produce positive stock returns over a twelve-month period. This study provides evidence that the puzzling relationships suggested by a previous study are sample-dependent and cannot withstand further scrutiny. Test results presented in this study show that investors are not likely to earn abnormal returns through an investment strategy constructed on the expectation of long-term positivie returns following a reduction in interest rates.
\end{abstract}

Keywords: stock returns, interest rates, market efficiency, information asymmetry

\section{Introduction}

The relationships between interest rates and stock returns have been the subject of a considerable amount of research. There is compelling evidence that stock returns are inversely related to interest rates. Thus, investors assume that an increase in interest rates would result in a reduction in stock returns, while a reduction in interest rates would have the opposite effect. Various reasons have been given to explain why changes in interest rates affect stock returns. In dividend discount models, the price of a stock basically reflects the present value of all its future cash flows. Therefore, changes in interest rates would affect stock prices by altering the discount rates used in calculating their present value, even when all of the firm's cash flows remain the same.

Lobo (2000) points out that the stock market reacts to the actions and utterances of the Federal Reserve Bank and its officials. He notes that interest rates changes can impact equity prices through two channels. First, by affecting the rate at which the firm's cash flows will be capitalized, and second, by altering expectations of future cash flows. Higher interest rates imply that firms would see increased cost of financing. All things being equal, increased cost of funds would impact negatively on the firm's profitability and its stock prices; while reductions in interest rates would have the opposite effect. Lobo notes that announcements of interest rate changes convey new information to the stock market, and investors generally respond according to the perceived effects of the new information. Portfolio allocation rules are often shaped by monetary policies, and investment advisors rely on these policies as a major factor in the portfolio selection process.

While market efficiency does not rule out an inverse relationship between stock returns and interest rates, it does rule out situations where a change in interest rates in one month is followed by long-term effect on stock returns over many months. However, the study by Domian, Gilster, and Louton (1996) document long-lived asymmetric relationship between reductions in interest rates and future stock returns. They show that a reduction in interest rate in one month produces positive stock returns over the next twelve months. Studies that suggest long-term positive or negative returns following an event (change in interest rates, in this case) have enormous implications for the investment behavior of agents. Investors may be eager to construct their portfolios on the expectation that a reduction in interest rates in a given month would produce positive returns for many months in the future. Again, these types of return anomalies challenge the validity of the efficient market hypothesis, which posits that stock returns at any point reflect all publicly available information at that point.

This study uses new datasets to re-examine the puzzling result of long-lived positive stock returns following a reduction in interest rates, as documented in Domian, Glister, and Luoton (henceforth, DGL 1996). It is important to re-examine the long-lived asymmetrical relationship documented in DGL in order to confirm the 
validity of that relationship. Results presented in this paper do not confirm the existence of long-term positive stock returns following a reduction in interest rates. Therefore, this study provides evidence that investors are not likely to achieve abnormal returns through an investment strategy predicated on the expectation of a long-term positive stock return following a reduction in interest rates. The rest of this paper proceeds as follows: Section 2 provides a review of related literature. Section 3 describes the data and methodology used in this study. Test results are presented in Section 4, while concluding remarks are provided in Section 5.

\section{Literature Review}

The relationship between interest rates and stock returns has been a popular area of research over the years. Earlier studies such as those of Waud (1970), Nelsson (1976), Fama and Schwert (1977) and Fama (1981) provide evidence of a negative relationship between interest rates and stock returns. This pattern of relationship has also been corroborated by more recent studies, such as those by Chen and Chan (1989), Staikouras (2003), Ferrer, Bolos and Benitoz (2016), among others. However, what has also emerged in the literature is that the nature of the relationship between interest rates and stock returns varies over time and across different business cycles (Yourougou, 1990; Basistha \& Kurov, 2008). Basistha and Kurov (2008) show that the stock market generally reacts more strongly to unexpected changes in interest rates in periods of recessions and unfriendly credti market, while Jansen and Tsai (2010) document stronger effects of rate changes on stock returns under a bear market than when the market is bullish. In addition, the stock returns response model is also not uniform across countries (Ferrer Bolos \& Benitoz, 2016). These studies show that the nature of stock market reactions to changes in interest rates is affected by several other factors.

Geske and Roll (1983) show the existence of inverse relationship between stock returns and expected and unexpected inflation. However, they argue that this relationship does not indicate causality. According to them, stock returns may be negatively correlated with changes in Treasury bill rates (the proxy for expected inflation) even when there is no direct connection between stock returns and inflation. A change in the real rate of interest should be a true cause of ex-post stock returns, because an increase (decrease) in the real interest rate induces a reduction (increase) in all asset values. Thus, to the extent that changes in Treasury bill rates are due to changes in the real interest rates component, one would expect a contemporaneous stock return in the opposite sign.

Fama (1981) provides an explanation for the inverse stock return-interest rate relationship. He argues that the negative relation between stock returns and interest rates is a proxy for positive relationship between stock returns and real variables, which are fundamental determinants of equity values. In this case, an increase in interest rates affects a firm's performance by raising the firm's cost of borrowing, and in some cases, reducing aggregate demand for the firm' products as consumers avoid the credit market and in the process moderate consumption. An increase in interest rates could raise the firm's cost of fund or lead to redcutions in demand; or both. Given either of these situations, the firm's performance and profitability would reduce, and with it, its stock returns. In effect, one would say that the negative relationship between interest rates and real activities or firms' proftiability accounts for the negative relationship between interest rates and stock returns.

In an analysis of the nature of sensitivity of banks' stock returns to interest rates, Flannery and James (1984) show that the common stock returns of commercial banks and stock savings and loan associations are highly correlated with interest rates changes. However, they found that the degree of correlation is positively related to the size difference between the banks' assets and liabilities. Along the same lines, Chen and Chan (1989) study the asymmetry between interest rates and stock returns of financial institutions. They provide evidence of some asymmetrical interest rates sensitivities during various interest rates cycles, and argue that the nature of the sensitivity at any given point is dependent on the current interest rates cycle and existing monetary policy regime. Their study underscores the importance of taking into account the prevailing monetary policy regime in analyzing the relationship between interest rates and stock returns. The present study shares the wisdom in Chen and Chan (1989). The choice of the pre- and post-1979 sub-periods is due to the major shift in monetary policy of October 1979, which produced well-documented effects in the financial markets (Spindt \& Tarhan, 1987; Vilasuso, 1999). Also, an examination of the relationship between interest rates and stock returns in the 1992 to 2015 subperiod is designed to document the nature of this relationship using an entirely new dataset, since the results in DGL are based on data from 1952 to 1991.

DGL estimate the relationship between changes in interest rates and stock returns for the periods 1952 to 1991 , and 1953 to 1992 (two different models). They show that a reduction in interest rates in one month is followed by positive stock returns over the next 12 months. Although their results portend a major challenge to market efficiency, and potentially have enormous implications for investors' behavior, no attempt has been made to subject these abnormal results to further tests. Consequently, this paper provides evidence that the results 
presented by DGL are dependent on their sample, and do not hold true when subjected to further scrutiny. One major factor that may account for the differences in the asymetric response to stock returns following interest rates changes is the 1979 change in Federal Reserve operating procedure. In October 1979, the Federal Reserve shifted from a policy of targeting interest rates to a reserve-oriented procedure. Axilrod and Lindsey (1981) show that the post- 1979 operating procedure resulted in a large volatility in interest rates. They show that the standard deviation of monthly changes in the federal funds rate increased almost ten-fold from the year before the policy change to the year following the change. As would be expected, Friedman (1982), O'Brien (1984), and Walsh (1984) document various forms of structural changes within the capital markets following the shift in the Fed's operating procedure.

While several studies highlighted above provide evidence of an inverse relationship between interest rates and stock returns, the concern of this paper is with the long-lived asymmetrical relationship documented in DGL. The results of long-lived positive returns following a reduction in interes rates deserve further scrutiny for two major reasons. First, the results could have serious implications on the investment behavior of agents, and second, it questions the hypothesis of market efficiency, which postulates that stock returns fully reflect all available information at any given time. One of the many ways to test the validity of any research finding is to test the same data using a different methodology, or to conduct tests using new datasets. This paper re-examines the results documented in DGL using new datasets.

\section{Data and Methodology}

The data for this analysis consist of monthly stock returns on the S\&P 500 index, and yields on three-month Treasury bills from January 1952 to December 2016. Changes in Treasury bill yields are good indicators of the direction of various interest rate series. Stock returns from January 1952 to December 1999 are obtained from the SBBI database; and data from 2000 to 2016 are obtained from the St. Louis Federal Reserve Bank. We denote this series by $S_{T O C K}$. Three-month Treasury bill yields are obtained from the St. Louis Federal Reserve Bank. Changes in yield are denoted by $T B I L L_{t}$ computed from $\left(Y I E L D_{t}-Y I E L D_{t-1}\right) / Y I E L D_{t-1}$.

\subsection{Unit Root Tests}

The stock returns and Treasury bill yields used in this paper are time series processes. Therefore, it is appropriate to test for stationarity of the series before carrying on with our tests. If the series are non-stationary, then the results of all conventional estimation would be invalid, and any conclusions drawn from the test results could be misleading. We test for non-stationarity of the processes using the augmented Dickey-Fuller $(1979,1981)$ unit root test. For any given series $Y_{\mathrm{t}}$, the existence of a unit root can be tested using the Dickey-Fuller stationarity test equation thus:

$$
Y_{t}=\beta+\delta_{t}+\rho Y_{t-1}+\Sigma \phi_{t} \Delta Y_{t-1}+\varepsilon_{t}
$$

For both the $S T O C K_{t}$ and $T B I L L_{t}$ series, the null hypothesis of a unit root is rejected at the $1 \%$ level. These results indicate that the series are stationary; as such, the regression test statistics are valid.

\subsection{Asymmetric Response Model}

It has been noted (see DGL) that separating interest rate changes into negative (reduction) and positive (increase) is necessary to detect whether the magnitude of stock returns response depends on the direction of the interest rates change. Similarly, in his study of money supply changes and output, Cover (1992) created a series containing positive money supply shocks, and another series containing only negative shocks. Therefore, we define TBILLPOS ${ }_{t}$ and $T_{B I L L N E G_{t}}$ thus:

$$
\begin{aligned}
\text { TBILLPOS }_{\mathrm{t}} & =\left\{\begin{array}{l}
\text { TBILL }_{t} \text { if } \text { TBILL }_{t} \geq 0 \\
0.0000 \text { if } \text { TBILL }_{t}<0
\end{array}\right. \\
\text { TBILLNEG }_{\mathrm{t}} & =\left\{\begin{array}{l}
\text { TBILL } L_{t} \text { if } \text { TBILL }_{t}<0 \\
0.0000 \text { if } \text { TBILL }_{t} \geq 0
\end{array}\right.
\end{aligned}
$$

TBILLPOS $S_{t}$ represents increase in interest rates, while $T B I L L N E G_{t}$ represents reduction in interest rates at time $t$.

Cumulative stock returns, $R E T k_{t}$ for periods 1 to 12 are defined as follows:

$$
\begin{aligned}
& \text { RET1 }_{t}=\text { STOCK }_{t+1} \\
& \operatorname{RET2}_{t}=\left(1+\text { STOCK }_{t+2}\right)\left(1+\text { STOCK }_{t+1}\right)-1 \\
& \operatorname{RET12}_{t}=\left(1+\operatorname{STOCK}_{t+12}\right)\left(1+\operatorname{STOCK}_{t+11}\right) \ldots\left(1+\operatorname{STOCK}_{t+1}\right)-1
\end{aligned}
$$

where $\operatorname{STOCK}_{t}$ is the total return on the S\&P 500 at month $t$. 
Each $R E T k_{\mathrm{t}}$ measures total return on the S\&P 500 over $k$ months following an interest rates change at time $t$. By estimating the following model,

$$
\text { RETk }_{t}=\alpha+\beta_{1} \text { TBILLPOS }_{t}+\beta_{2} \text { TBILLNEG }_{t}+\varepsilon_{t}
$$

This study evaluates the response of cumulative stock returns following a change in interest rates at time $t$.

In equation (2), for $k>1$, the RETk series uses stock returns from overlapping months. Therefore, even though the sample period is from January 1952 to December 2016, the estimation period is from January 1952 to December 2015. Stock returns up to December 2016 are used to construct the December 2015 value for RET12. As in DGL, we use the Newey-West (1987) method to adjust the standard errors for autocorrelation induced by the overlaps.

\section{Results}

DGL used an estimation period from 1952 to 1991 and find evidence of a long-lived asymmetrical relationship between stock returns and interest rates. This paper extends the estimation period to 2015. In addition, tests are conducted on different subperiods.

Table 1. Cumulative stock responses to changes in interest rate, 1952 to 1991

\begin{tabular}{|c|c|c|c|c|}
\hline$k$ & $\hat{\alpha}$ & $\hat{\beta}_{1}$ & $\hat{\beta}_{2}$ & $R^{2}$ \\
\hline \multirow[t]{2}{*}{1} & $0.009 * *$ & -0.023 & $-0.087^{*}$ & 0.013 \\
\hline & $(0.000)$ & $(0.553)$ & $(0.015)$ & \\
\hline \multirow[t]{2}{*}{2} & $0.015 * *$ & 0.026 & $-0.189 * *$ & 0.022 \\
\hline & $(0.000)$ & $(0.539)$ & $(0.001)$ & \\
\hline \multirow[t]{2}{*}{3} & $0.023 * *$ & 0.062 & $-0.259 * *$ & 0.027 \\
\hline & $(0.000)$ & $(0.278)$ & $(0.001)$ & \\
\hline \multirow[t]{2}{*}{4} & $0.030 * *$ & 0.079 & $-0.344 * *$ & 0.034 \\
\hline & $(0.000)$ & $(0.308)$ & $(0.000)$ & \\
\hline \multirow[t]{2}{*}{5} & $0.039 * *$ & 0.051 & $-0.447 * *$ & 0.045 \\
\hline & $(0.000)$ & $(0.581)$ & $(0.000)$ & \\
\hline \multirow[t]{2}{*}{6} & $0.047 * *$ & 0.079 & $-0.548 * *$ & 0.053 \\
\hline & $(0.000)$ & $(0.378)$ & $(0.000)$ & \\
\hline \multirow[t]{2}{*}{7} & $0.055^{* *}$ & 0.114 & $-0.622 * *$ & 0.056 \\
\hline & $(0.000)$ & $(0.248)$ & $(0.000)$ & \\
\hline \multirow[t]{2}{*}{8} & $0.063 * *$ & 0.155 & $-0.673 * *$ & 0.057 \\
\hline & $(0.000)$ & $(0.154)$ & $(0.000)$ & \\
\hline \multirow[t]{2}{*}{9} & $0.073 * *$ & 0.148 & $-0.728 * *$ & 0.058 \\
\hline & $(0.000)$ & $(0.223)$ & $(0.000)$ & \\
\hline \multirow[t]{2}{*}{10} & $0.081 * *$ & 0.146 & $-0.849 * *$ & 0.071 \\
\hline & $(0.000)$ & $(0.286)$ & $(0.000)$ & \\
\hline \multirow[t]{2}{*}{11} & $0.088^{* *}$ & 0.197 & $-0.962 * *$ & 0.082 \\
\hline & $(0.000)$ & $(0.241)$ & $(0.000)$ & \\
\hline \multirow[t]{2}{*}{12} & $0.098^{* *}$ & 0.172 & $-1.016^{* *}$ & 0.084 \\
\hline & $(0.000)$ & $(0.331)$ & $(0.000)$ & \\
\hline
\end{tabular}

p-values are shown in parentheses.

* Significantly different from zero at the $5 \%$ level.

$* *$ Significantly different from zero at the $1 \%$ level.

Table 1 presents estimation results for the 1952 to 1991 period shown in DGL. As shown in the table, increases in interest rates (TBILLPOS) do not have significant effects on stock returns. However, the TBILLNEG coefficients are all significant, usually at the $1 \%$ level ( $p$-values range from 0.00 to 0.015 ). This result would imply the existence of a long-term inverse relationships between interest rates and stock returns. In effect, investors may believe that a reduction in interest rates in one month would produce positive stock returns for the next twelve months. 
Table 2. Cumulative stock responses to changes in interest rate, 1992 to 2015

\begin{tabular}{|c|c|c|c|c|}
\hline$k$ & $\hat{\alpha}$ & $\hat{\beta}_{1}$ & $\hat{\beta}_{2}$ & $R^{2}$ \\
\hline \multirow[t]{2}{*}{1} & $0.023^{*}$ & -0.061 & -0.163 & 0.080 \\
\hline & $(0.033)$ & $(0.810)$ & $(0.373)$ & \\
\hline \multirow[t]{2}{*}{2} & $0.033^{*}$ & -0.138 & -0.179 & 0.012 \\
\hline & $(0.032)$ & $(0.931)$ & $(0.621)$ & \\
\hline \multirow[t]{2}{*}{3} & $0.025^{*}$ & -0.167 & -0.096 & 0.021 \\
\hline & $(0.024)$ & $(0.513)$ & $(0.671)$ & \\
\hline \multirow[t]{2}{*}{4} & $0.074 * *$ & -0.174 & -0.139 & 0.011 \\
\hline & $(0.001)$ & $(0.431)$ & $(0.832)$ & \\
\hline \multirow[t]{2}{*}{5} & $0.095^{* *}$ & -0.183 & -0.048 & 0.005 \\
\hline & $(0.001)$ & $(0.549)$ & $(0.387)$ & \\
\hline \multirow[t]{2}{*}{6} & $0.027^{*}$ & -0.168 & -0.243 & 0.008 \\
\hline & $(0.022)$ & $(0.480)$ & $(0.698)$ & \\
\hline \multirow[t]{2}{*}{7} & $0.095^{* *}$ & -0.438 & -0.245 & 0.006 \\
\hline & $(0.001)$ & $(0.482)$ & $(0.871)$ & \\
\hline \multirow[t]{2}{*}{8} & $0.108^{* *}$ & -0.531 & -0.278 & 0.011 \\
\hline & $(0.004)$ & $(0.435)$ & $(0.871)$ & \\
\hline \multirow[t]{2}{*}{9} & $0.156^{* *}$ & -0.627 & 0.174 & 0.024 \\
\hline & $(0.002)$ & $(0.274)$ & $(0.791)$ & \\
\hline \multirow[t]{2}{*}{10} & $0.178^{* *}$ & -0.683 & 0.394 & 0.013 \\
\hline & $(0.003)$ & $(0.842)$ & $(0.895)$ & \\
\hline \multirow[t]{2}{*}{11} & $0.273^{*}$ & -0.364 & 0.492 & 0.009 \\
\hline & $(0.018)$ & $(0.499)$ & $(0.862)$ & \\
\hline \multirow[t]{2}{*}{12} & $0.171^{*}$ & -0.502 & 0.468 & 0.008 \\
\hline & $(0.015)$ & $(0.472)$ & $(0.859)$ & \\
\hline
\end{tabular}

Note. p-values are shown in parentheses. * Significantly different from zero at the 5\% level. ** Significantly different from zero at the $1 \%$ level.

The estimation period used by DGL ended in 1991. In order to test the robustness of their results under current market conditions, we conduct out-of-sample tests, using the 1992 to 2015 estimation period. Test results are presented in Table 2 above. Contrary to the results for the 1952 to 1991 period, all the coefficients of TBILLNEG in Table 2 are statistically insignificant ( $p$-values range from 0.39 to 0.97 ). This shows that a reduction in interest rates does not induce long-term positive stock returns documented in DGL. The recent evidence does not support the existence of a long-term asymmetrical relationship. Thus, it would be misleading if an investment strategy were constructed with the expectation of long-term positive stock returns following a reduction in interest rates.

Table 3. Cumulative stock responses to changes in interest rate, 1952-Sept. 1978

\begin{tabular}{|c|c|c|c|c|}
\hline$k$ & $\hat{\alpha}$ & $\hat{\beta}_{1}$ & $\hat{\beta}_{2}$ & $R^{2}$ \\
\hline \multirow[t]{2}{*}{1} & $0.007 *$ & -0.008 & -0.073 & 0.009 \\
\hline & $(0.012)$ & $(0.827)$ & $(0.071)$ & \\
\hline \multirow[t]{2}{*}{2} & $0.011^{*}$ & 0.047 & $-0.160 * *$ & 0.018 \\
\hline & $(0.031)$ & $(0.217)$ & $(0.003)$ & \\
\hline \multirow[t]{2}{*}{3} & $0.015^{*}$ & 0.095 & $-0.261 * *$ & 0.034 \\
\hline & (0.038) & $(0.065)$ & $(0.000)$ & \\
\hline \multirow[t]{2}{*}{4} & $0.020^{*}$ & 0.118 & $-0.388 * *$ & 0.051 \\
\hline & $(0.045)$ & $(0.097)$ & $(0.000)$ & \\
\hline \multirow[t]{2}{*}{5} & $0.027 *$ & 0.099 & $-0.490 * *$ & 0.058 \\
\hline & $(0.031)$ & $(0.246)$ & $(0.000)$ & \\
\hline \multirow[t]{2}{*}{6} & $0.033^{*}$ & 0.135 & $-0.589 * *$ & 0.066 \\
\hline & $(0.027)$ & $(0.096)$ & $(0.000)$ & \\
\hline \multirow[t]{2}{*}{7} & $0.038^{*}$ & 0.177 & $-0.680 * *$ & 0.074 \\
\hline & $(0.023)$ & $(0.583)$ & $(0.000)$ & \\
\hline \multirow[t]{2}{*}{8} & $0.043^{*}$ & $0.221^{*}$ & $-0.786 * *$ & 0.086 \\
\hline & (0.023) & $(0.030)$ & $(0.000)$ & \\
\hline \multirow[t]{2}{*}{9} & $0.050^{*}$ & $0.224^{*}$ & $-0.876^{* *}$ & 0.092 \\
\hline & $(0.017)$ & $(0.049)$ & $(0.000)$ & \\
\hline
\end{tabular}




\begin{tabular}{ccccc}
\hline 10 & $0.055^{*}$ & 0.249 & $-1.016^{* *}$ & 0.109 \\
& $(0.015)$ & $(0.055)$ & $(0.000)$ & 0.125 \\
11 & $0.058^{*}$ & 0.328 & $-1.136^{* *}$ & \\
& $(0.015)$ & $(0.058)$ & $(0.000)$ & 0.126 \\
\hline \multirow{2}{*}{12} & $0.067^{*}$ & 0.296 & $-1.210^{* *}$ & $(0.000)$ \\
& $(0.011)$ & $(0.110)$ & & \\
\hline
\end{tabular}

Note. p-values are shown in parentheses. * Significantly different from zero at the $5 \%$ level. ** Significantly different from zero at the $1 \%$ level.

In October 1979, the Federal Reserve shifted from a policy of targeting interest rates to a reserve-oriented procedure. As noted in Chen and Chan (1989), it is necessary to take into account prevailing monetary policy regimes in analyzing the relationship between interest rates and stock returns. To this end, we test for the existence of long-term asymmetry prior to the change in the Fed's operating policy. Estimation results for the January 1952 to September 1978 subperiod are presented in Table 3 above. Consistent with the results shown by DGL, a reduction in interest rates in a given month continues to induce large positive stock returns for the next 12 months. With most $p$-values approximately 0 , the coefficients of TBILLNEG remain statistically significant for months 2 through 12 .

Table 4. Cumulative stock responses to changes in interest rate, Oct. 1978-2015

\begin{tabular}{|c|c|c|c|c|}
\hline$k$ & $\hat{\alpha}$ & $\hat{\beta}_{1}$ & $\hat{\beta}_{2}$ & $R^{2}$ \\
\hline \multirow[t]{2}{*}{1} & $0.172 *$ & -0.087 & -0.354 & 0.032 \\
\hline & $(0.050)$ & $(0.365)$ & $(0.128)$ & \\
\hline \multirow[t]{2}{*}{2} & $0.085^{* *}$ & -0.149 & -0.472 & 0.047 \\
\hline & $(0.000)$ & $(0.812)$ & (0.084) & \\
\hline \multirow[t]{2}{*}{3} & $0.019^{* *}$ & -0.141 & -0.412 & 0.028 \\
\hline & $(0.001)$ & $(0.831)$ & (0.158) & \\
\hline \multirow[t]{2}{*}{4} & $0.128^{*}$ & -0.243 & -0.863 & 0.056 \\
\hline & $(0.041)$ & $(0.921)$ & $(0.197)$ & \\
\hline \multirow[t]{2}{*}{5} & $0.095^{* *}$ & -0.095 & -0.285 & 0.031 \\
\hline & $(0.000)$ & $(0.781)$ & $(0.181)$ & \\
\hline \multirow[t]{2}{*}{6} & $0.145^{* *}$ & -0.095 & -0.542 & 0.082 \\
\hline & $(0.001)$ & $(0.839)$ & $(0.143)$ & \\
\hline \multirow[t]{2}{*}{7} & $0.137 * *$ & -0.167 & -0.561 & 0.049 \\
\hline & $(0.000)$ & $(0.715)$ & $(0.183)$ & \\
\hline \multirow[t]{2}{*}{8} & $0.132 * *$ & -0.145 & -0.541 & 0.021 \\
\hline & $(0.000)$ & $(0.975)$ & $(0.185)$ & \\
\hline \multirow[t]{2}{*}{9} & $0.097^{* *}$ & -0.457 & -0.394 & 0.054 \\
\hline & $(0.000)$ & $(0.887)$ & $(0.138)$ & \\
\hline \multirow[t]{2}{*}{10} & $0.165^{* *}$ & -0.425 & -0.532 & 0.038 \\
\hline & $(0.001)$ & $(0.670)$ & (0.195) & \\
\hline \multirow[t]{2}{*}{11} & $0.137 * *$ & -0.327 & -0.624 & 0.042 \\
\hline & $(0.000)$ & $(0.467)$ & $(0.142)$ & \\
\hline \multirow[t]{2}{*}{12} & $0.092 * *$ & -0.385 & -0.314 & 0.065 \\
\hline & $(0.000)$ & $(0.491)$ & $(0.318)$ & \\
\hline
\end{tabular}

Note. p-values are shown in parentheses. * Significantly different from zero at the $5 \%$ level. ** Significantly different from zero at the $1 \%$ level.

Many studies such as Friedman (1982), O’Brien (1984), and Walsh (1984) document various forms of structural changes in the capital markets following the shift in the Fed's operating procedure in October 1979. We investigate the relationship between interest rates and stock returns for the October 1979 to December 2015 subperiod. The results are presented in Table 4 above. As shown in the table, the TBILLPOS coefficients are all negative and statistically insignificant. Similarly, none of the TBILLNEG coefficients is significant at the 5\% level. It is clear from this result that the long-term asymmetrical relationship between stock returns and interest rates suggested by DGL is sample-dependent, and does not reflect the nature of the relationship between interest rates and stock returns based on current data. 
Fama (1998) notes that market efficiency continues to survive the challenge from the growing literature on long-term return anomalies. This study provides yet another confirmation that findings of return anomalies can be attributed to a number of factors, including the sample, methodology, economic cycle and chance. As such, studies that sometimes document return anomalies do not necessarily invalidate the hypothesis of market efficiency.

\section{Conclusion}

Recent studies suggest the existence of long-term return anomalies, thus questioning the validity of the market efficiency hypothesis. This paper subjects one of such studies to further scrutiny by considering more recent data. This study provides evidence that findings of long-term excess stock returns following a reduction in interest rates are sample-dependent. When tested with new datasets, the long-term abnormal returns disappear, suggesting that the reported return anomalies are only a chance occurrence and do not reflect the true relationship between interest rates and stock returns.

As noted by Chen and Chan (1989), it is necessary to take existing monetary policy regimes into account in analyzing interest rate asymmetries. Therefore, this study conducts similar tests for two periods coinciding with the change in Federal Reserve operating procedure of October 1979. While the results for the pre-1979 period confirm the puzzling results documented in DGL, tests for the post-1979 period could not reveal any form of long-term relationship.

Based on these findings, this study concludes that it would be inappropriate to assume that a reduction in interest rates in a given month will be followed by 12 months of positive stock returns. Results presented in this study provide evidence that investors are not likely to earn abnormal returns by embarking on an investment strategy predicated on a long-term asymmetrical relationship between interest rates and stock returns. Therefore, this paper provides another victory for market efficiency.

\section{References}

Axilrod, S. H., \& Lindsey, D. E. (1981). Federal Reserve System implementation of monetary policy: Analytical foundations of the new approach. Papers and Proceedings of the American Economic Association, 94, 246-252.

Basistha, A., \& Kurov, A. (2008). Macroeconomic cycles and the stock market's reaction to monetary policy. Journal of Banking and Finance, 32, 2606-2616. http://doi.org/10.1016/j.jbankfin.2008.05.012

Chen, R. C., \& Chan, A. (1989). Interest rate sensitivity, asymmetry, and stock returns of financial institutions. The Financial Review, 24, 457-473. https://doi.org/10.1111/j.1540-6288.1989.tb00352.x

Cover, J. (1992). Asymmetric effects of positive and negative money-supply shocks. Quarterly Journal of Economics, 107, 1261-1282. https://doi.org/10.2307/2118388

Dickey, D., \& Fuller, W. (1979). Distribution of the estimators for autoregressive time series with a unit root. Journal of the American Statistical Society, 74, 427-431. https://doi.org/10.1080/01621459.1979.10482531

Dickey, D., \& Fuller, W. (1981). Likelihood ratio statistics for autoregressive time series with a unit root. Econometrica, 49, 1057-1072. https://doi.org/10.2307/1912517

Domian, D. L., Gilster, J. E., \& Louton, D. A. (1996). Expected inflation, interest rates and stock returns. The Financial Review, 31, 809-830. https://doi.org/10.1111/j.1540-6288.1996.tb00898.x

Fama, E. F. (1981). Stock returns, real activity, inflation, and money. American Economic Review, 71, 545-565.

Fama, E. F. (1998). Market efficiency, long-term returns, and behavioral finance. Journal of Financial Economics, 49, 283-306. https://doi.org/10.1016/S0304-405X(98)00026-9

Fama, E. F., \& Schwert, G. W. (1984). Asset returns and inflation. Journal of Financial Economics, 2, 115-146.

Ferrer, R., Bolos, J. V., \& Benitez, R. (2016). Interest rate changes and stock returns: A European multi-country study with wavelet. International Review of Economics and Finance, 44, 1-12. http://doi.org/10.1016/j.iref.2016.03.001

Flannery, M. J., \& James, C. M. (1984). The effects of interest rate changes on common stock returns of financial institutions. The Journal of Finance, 34, 1141-1153. https://doi.org/10.1111/j.1540-6261.1984.tb03898.x

Friedman, B. M. (1982). Federal Reserve policy, interest rate volatility, and the U.S. capital raising mechanism. Journal of Money, Credit, and Banking, 14, 721-745. https://doi.org/10.2307/1991559 
Geske, R., \& Roll, R. (1983). The monetary and fiscal linkage between stock returns and inflation. The Journal of Finance, 38, 1-33. https://doi.org/10.1111/j.1540-6261.1983.tb03623.x

Jansen, D. W., \& Tsai, C. L. (2010). Monetary policy and stock returns: Financing constraints and asymmetries in bull and bear markets. Journal of Empirical Finance, 17, 981-990. http://doi.org/10.1016/j.jempfin.2010.08.002

Jensen, G. R., \& Johnson, R. R. (1995). Discount rate changes and security returns in the U.S., 1962-1991. Journal of Banking and Finance, 19, 79-95. https://doi.org/10.1016/0378-4266(94)00048-8

Kim, S., \& In, F. (2011). On the relationship between changes in stock prices and bond yields in the G7 countries: wavelet analysis. Journal of International Financial Market Institutions and Money, 17, 167-179. http://doi.org/10.1016/j.intfin.2005.10.004

Lobo, B. J. (2000). Asymmetric effects of interest rate changes on stock prices. The Financial Review, 35, 125-144. https://doi.org/10.1111/j.1540-6288.2000.tb01424.x

Nelson, C. R. (1976). Inflation and rates of return on common stocks. The Journal of Finance, 31, 471-487. https://doi.org/10.1111/j.1540-6261.1976.tb01900.x

Newey, W., \& West, K. (1987). A simple positive semi-definite, heteroskedasticity and autocorrelation consistent covariance matrix. Econometrica, 55, 703-708. https://doi.org/10.2307/1913610

O'Brien, J. M. (1984). The information value of the FOMC policy directive under the new operating procedures. Journal of Money, Credit, and Banking, 16, 151-164. https://doi.org/10.2307/1992541

Roley, V. V., \& Troll, D. (1984). The impact of discount rate changes on market interest rates. Federal Reserve Bank of Kansas City Economic Review, 69, 27-39.

Smirlock, M., \& Yawitz, J. (1985). Asset returns, discount rate changes, and market efficiency. The Journal of Finance, 40, 1141-1158. https://doi.org/10.1111/j.1540-6261.1985.tb02368.x

Spint, P., \& Tarhan, V. (1987). The Federal Reserve operating procedures: A post-mortem. Journal of Monetary Economics, 19, 107-123. https://doi.org/10.1016/0304-3932(87)90031-6

Staikouras, S. K. (2003). The interest rate risk exposure of financial intermediaries: A review of the theory and empirical evidence. Financial Markets, Institutions and Instruments, 12, 257-289. https://doi.org/10.1111/1468-0416.t01-1-00002

Vilasuso, J. (1999). The liquidity effect and the operating procedure of the Federal Reserve. Journal of Macroeconomics, 21, 443-461. https://doi.org/10.1016/S0164-0704(99)00111-1

Walsh, C. E. (1984). Interest rate volatility and monetary policy. Journal of Money, Credit, and Banking, 16, 133-164. https://doi.org/10.2307/1992540

Waud, R. N. (1970). Public interpretation of Federal Reserve discount rate changes: Evidence on the “Announcement Effect". Econometrica, 38, 231-250. https://doi.org/10.2307/1913006

Yourougou, P. (1990). Interest-rate risk and pricing of depository financial intermediary common stock: Empirical evidence. Journal of Banking and Finance, 4, 803-820. https://doi.org/10.1016/0378-4266(90)90077-F

\section{Copyrights}

Copyright for this article is retained by the author(s), with first publication rights granted to the journal.

This is an open-access article distributed under the terms and conditions of the Creative Commons Attribution license (http://creativecommons.org/licenses/by/4.0/). 